\title{
PENINGKATAN KOMPETENSI GURU DALAM MENYUSUN RENCANA PELAKANAAN PEMBELAJARAN MELALUI PENDAMPINGAN BERKELANJUTAN DI SMPN SATU ATAP I BAJAWA KECAMATAN BAJAWA KABUPATEN NGADA TAHUN 2019
}

\author{
Wunu Veronika \\ SMPN Satu Atap I Bajawa \\ Kabupaten Ngada Nusa Tenggara Timur \\ e-Mail:wunuveronika@gmail.com
}

\begin{abstract}
Abstrak
Penelitian ini bertujuan untuk meningkatkan kompetensi guru dalam menyusun rencana pelaksanaan pembelajaran (RPP) pada Kurikulum 2013 melalui Pendampingan yang berkelanjutan. Subjek dalam penelitian ini adalah Guru-guru SMPN SATAP I Bajawa. Penelitian ini terdiri dari dua siklus, setiap siklus terdiri dari empat tahap yaitu perencanaan tindakan, akting, pengamatan, dan refleksi. Pada umumnya, RPP yang digunakan belum sesuai dengan RPP standar dan belum mematuhi kaidah-kaidah penyusunan RPP. Hal ini terjadi karena kurangnya kemampuan guru dalam menyusun RPP dan juga untuk pemetaan materi yang tertera dalam silabus. Oleh karena itu, dibutuhkan bimbingan berkelanjutan yang dilakukan oleh kepala sekolah dalam menyusun RPP dan juga untuk meningkatkan kemampuan guru. Metode yang digunakan adalah Metode Penelitian Tindakan Sekolah dengan 2 (dua) siklus. Pengumpulan data menggunakan metode observasi, wawancara, dan angket. Terkait dengan permasalahan di atas, perlu adanya bantuan penanganan yang memadai. Dalam hal ini, upaya yang dilakukan adalah dengan melaksanakan pendampingan, yang bertujuan pada peningkatan kompetensi guru melalui siklus yang sistematis. Teknik analisis data adalah menggunakan diskriptif komparatif. Penelitian ini dilakukan dengan tahapan siklus, masing-masing siklus terdiri dari 4 (empat) langkah meliputi : perencanaan, pelaksanaan, pengamatan dan refleksi. Pada kondisi awal memperoleh nilai rata-rata kemampuan guru dalam menyusun RPP yakni 67,61. Pada siklus pertama memperoleh nilai ratarata kemampuan guru dalam menyusun RPP yakni 78,91. Pada siklus kedua memperoleh nilai rata-rata kemampuan guru dalam menyusun RPP adalah 91,47. Hasil penelitian ini, agar guru memiliki kebiasaan dan menunjukkan peningkatan kompetensi sesuai dengan indikator keberhasilan yang telah ditetapkan dalam menyusun RPP. Saran yang diajukan adalah : (1) perlu diintensifkan peningkatan kompetensi guru dalam menyusun RPP melalui kegiatan pendampingan atau sejenisnya (2) untuk meningkatkan kompetensi guru, sekolah, perlu adanya wahana semacam In House Training (IHT), agar mereka dapat saling bertukar pengalaman melalui dialog akademis.
\end{abstract}

Kata kunci: Kompetensi Guru Menyusun RPP, Pendampingan Berkelanjutan 


\begin{abstract}
This study aims to improve the competence of teachers in preparing a lesson plan (RPP) on Curriculum 2013 through ongoing mentoring. Subjects in this study were teachers SMPN SATAP I Bajawa. The study consisted of two cycles, each cycle consisting of four stages: planning the action, acting, observing and reflecting. In general, the RPP is used not in accordance with standard CSP and has not complied with the rules of preparation of the RPP. This happens because of the lack of ability of teachers in preparing lesson plans and also for mapping the material contained in the syllabus. Therefore, it needs continuous counseling conducted by the principals in preparing the RPP and also to improve the ability of teachers. The method used is the method of Action Research School with two (2) cycles. Related to the above problems, the need for adequate management assistance. In this regard, the efforts made by implementing the assistance, which aims at improving the competence of teachers through a systematic cycle. The data analysis technique is using descriptive comparative. This research was conducted in stages, cycles, each cycle consisting of four (4) steps include: planning, implementation, observation and reflection, In the initial condition of obtaining the average value of the ability of teachers in preparing a lesson plan that is 67.61 . In the first cycle of obtaining the average value of the ability of teachers in preparing a lesson plan that is 78.91. In the second cycle obtain the average value of the ability of teachers in preparing the RPP is 91.47 , The results of this study, so that teachers have the habit and showed an increase of competence in accordance with predetermined indicators of success in preparing the RPP. Suggestions put forward are: (1) need to be intensified to increase the competence of teachers in preparing lesson plans through mentoring or the like (2) to improve the competence of teachers, schools, the need for some sort of vehicleln House Training (IHT), so that they can exchange experience through academic dialogue.
\end{abstract}

Keywords: Develop Teacher Competence RPP, Sustainable Assistance

\section{PENDAHULUAN}

Pendidikan merupakan
investasi dalam pengembangan
sumber daya manusia dan dipandang sebagai kebutuhan dasar bagi masyarakat yang ingin maju. Komponen-komponen sistem pendidikan yang mencakup sumber daya manusia dapat digolongkan menjadi dua yaitu: tenaga kependidikan guru dan nonguru. Menurut UndangUndang Nomor 20 tahun 2003 tentang Sistem Pendidikan Nasional menyatakan, "komponenkomponen sistem pendidikan yang bersifat sumber daya manusia dapat digolongkan menjadi tenaga pendidik dan pengelola satuan pendidikan (penilik, pengawas, peneliti dan pengembang pendidikan)." Tenaga gurulah yang mendapatkan perhatian lebih banyak di antara komponenkomponen sistem pendidikan. Besarnya perhatian terhadap guru antara lain dapat dilihat dari banyaknya kebijakan khusus seperti kenaikan tunjangan fungsional guru dan sertifikasi guru. Usaha-usaha untuk mempersiapkan guru menjadi profesional telah banyak dilakukan. Kenyataan menunjukkan bahwa tidak semua guru memiliki kinerja yang baik dalam melaksanakan tugasnya. "Hal ini ditunjukkan dengan kenyataan (1) guru sering 
mengeluh kurikulum yang berubahubah, (2) guru sering mengeluhkan kurikulum yang syarat dengan beban, (3) seringnya siswa mengeluh dengan cara mengajar guru yang kurang menarik, (4) masih belum dapat dijaminnya kualitas pendidikan sebagai mana mestinya" (Imron, 2000:5).

Berdasarkan kenyataan begitu berat dan kompleksnya tugas serta peran guru tersebut, perlu diadakan supervisi atau pembinaan terhadap guru secara terus menerus untuk meningkatkan kinerjanya. Kinerja guru perlu ditingkatkan agar usaha membimbing siswa untuk belajar dapat berkembang. "Proses pengembangan kinerja guru terbentuk dan terjadi dalam kegiatan belajar mengajar di tempat mereka bekerja. Selain itu kinerja guru dipengaruhi oleh hasil pembinaan dan supervisi kepala sekolah" (Pidarta, 1992:3). Pada pelaksanaan Kurikulum 2013 menuntut kemampuan baru pada guru untuk dapat mengelola proses pembelajaran secara efektif dan efisien. Tingkat produktivitas sekolah dalam memberikan pelayanan-pelayanan secara efisien kepada pengguna (peserta didik, masyarakat) akan sangat tergantung pada kualitas gurunya yang terlibat langsung dalam proses pembelajaran dan keefektifan mereka dalam melaksanakan tanggung jawab individual dan kelompok. Direktorat Pembinaan Pendidikan Dasar (2008:3) menyatakan "kualitas pendidikan sangat ditentukan oleh kemampuan sekolah dalam mengelola proses pembelajaran, dan lebih khusus lagi adalah proses pembelajaran yang terjadi di kelas, mempunyai andil dalam menentukan kualitas pendidikan konsekuensinya, adalah guru harus mempersiapkan (merencanakan) segala sesuatu agar proses pembelajaran di kelas berjalan dengan efektif".

Hal ini berarti bahwa guru sebagai fasilitator yang mengelola proses pembelajaran di kelas mempunyai andil dalam menentukan kualitas pendidikan. Konsekuensinya adalah guru harus mempersiapkan (merencanakan) segala sesuatu agar proses pembelajaran di kelas berjalan dengan efektif.

Perencanaan pembelajaran merupakan langkah yang sangat penting sebelum pelaksanaan pembelajaran. Perencanaan yang matang diperlukan supaya pelaksanaan

pembelajaran berjalan secara efektif. Perencanaan pembelajaran dituangkan ke dalam Rencana Pelaksanaan Pembelajaran (RPP) atau beberapa istilah lain seperti desain pembelajaran, skenario pembelajaran. RPP memuat $\mathrm{KI}$, $\mathrm{KD}$, indikator yang akan dicapai, materi yang akan dipelajari, langkah pembelajaran, media pembelajaran, dan sumber belajar serta penilaian.

Guru harus mampu berperan sebagai desainer (perencana), implementor (pelaksana), dan evaluator (penilai) kegiatan pembelajaran. Guru merupakan faktor yang paling dominan karena di tangan gurulah keberhasilan pembelajaran dapat dicapai. Kualitas mengajar guru secara langsung maupun tidak langsung dapat mempengaruhi kualitas pembelajaran pada umumnya. Seorang guru dikatakan profesional apabila (1) serius melaksanakan tugas profesinya, (2) bangga dengan tugas profesinya 
, (3) selalu menjaga dan berupaya meningkatkan kompetensinya, (4) bekerja

dengan sungguh tanpa harus dia wasi, (5) menjaga nama baik $p$ rofesinya, (6) bersyukur atas imbalan yang diperoleh dari profesinya.

Peraturan Pemerintah Nomor 19 Tahun 2005 tentang 8 Standar Nasional Pendidikan menyatakan standar proses merupakan salah satu SNP untuk satuan pendidikan dasar dan menengah yang mencakup: 1) Perencanaan proses pembelajaran, 2) Pelaksanaan proses pembelajaran, 3) Penilaian hasil pembelajaran, 4) dan pengawasan proses pembelajaran. Perencanaan pembelajaran meliputi Silabus dan Rencana Pelaksanaan Pembelajaran (RPP). Silabus dan RPP dikembangkan oleh guru pada satuan pendidikan. Guru pada satuan pendidikan berkewajiban menyusun Silabus dan RPP secara lengkap dan sistematis agar pembelajaran berlangsung secara interaktif, inspiratif, menyenangkan, menantang, memotivasi peserta didik untuk berpartisipasi aktif, serta memberikan ruang yang cukup bagi prakarsa, kreativitas, dan kemandirian sesuai dengan bakat, minat dan perkembangan fisik serta psikologis peserta didik. Perencanaan pembelajaran merupakan langkah yang sangat penting sebelum pelaksanaan pembelajaran. Perencanaan yang matang diperlukan supaya pelaksanaan pengembangan berjalan secara efektif. PP Nomor 19 tahun 2005 yang berkaitan dengan standar proses, mengisyaratkan bahwa guru diharapkan dapat mengembangkan perencanaan pembelajaran, yang kemudian dipertegas melalui Permendiknas Nomor 41 tahun 2007 tentang standar proses, yang antara lain mengatur tentang perencanaan proses pembelajaran yang mensyaratkan bagi pendidik pada satuan pendidikan untuk mengembangkan Rencana Pelaksanaan Pembelajaran (RPP), khususnya pada jenjang pendidikan dasar dan menengah jalur formal, baik yang menerapkan sistem paket maupun Sistem Kredit Semester (SKS).

Rencana

Pelaksanaan

Pembelajaran (RPP), artinya rencana yang menggambarkan prosedur dan pengorganisasian pembelajaran untuk mencapai suatu kompetensi dasar yang ditetapkan dalam standar isi dan dijabarkan dalam silabus. Ruang lingkup RPP paling luas mencakup 1 (satu) kompetensi dasar yang terdiri atas 1 (satu) indikator atau beberapa indikator untuk 1 (satu) kali pertemuan atau lebih (Apribn, 2011:1)

Setiap guru pada satuan pendidikan berkewajiban menyusun RPP secara lengkap dan sistematis agar pembelajaran berlangsung secara interaktif, inspiratif, menyenangkan, menantang, memotivasi peserta didik untuk berpartisipasi aktif, serta memberi ruang yang cukup bagi prakasa, kreatifitas, dan kemandirian sesuai dengan bakat, minat dan pengembangan fisik serta psikologis peserta didik.

Dalam perencanaan, guru dituntut agar dapat menyusun sendiri Rencana Pelaksanaan Pembelajaran (RPP) sesuai dengan mata pelajaran yang diampunya. Tetapi pada umumnya guru menggunakan RPP yang diperoleh dari forum MGMP tanpa 
adanya penyesuaian dengan situasi dan kondisi sekolah masingmasing. Selain itu juga RPP yang digunakan belum sesuai dengan RPP standar dan belum mematuhi kaidah-kaidah penyusunan RPP. $\mathrm{Hal}$ ini terjadi karena kurangnya kemampuan guru dalam menyusun RPP.

Masalah yang terjadi di lapangan masih ditemukan adanya guru (baik di sekolah negeri maupun swasta) yang tidak bisa memperlihatkan RPP yang dibuat dengan alasan ketinggalan di rumah dan bagi guru yang sudah membuat RPP masih ditemukan adanya guru yang belum melengkapi komponen tujuan pembelajaran dan penilaian (soal, skor dan kunci jawaban), serta langkah-langkah kegiatan pembelajarannya masih dangkal. Soal, skor, dan kunci jawaban merupakan satu kesatuan yang tidak dapat dipisahkan. Pada komponen peni laian (penskoran dan kunci jawaban) sebagian besar guru tidak lengkap membuatnya dengan alasan sudah tahu dan ada di kepala. Sedangkan pada komponen tujuan pembelajaran, materi ajar, metode pembelajaran, dan sumber belajar sebagian besar guru sudah membuatnya. Masalah yang lain yaitu sebagian besar guru khususnya di sekolah swasta belum mendapatkan pelatihan pengembangan RPP. Selama ini guru-guru yang mengajar di sekolah swasta sedikit/jarang mendapatkan kesempatan untuk mengikuti berbagai Diklat Peningkatan Profesionalisme Guru dibandingkan sekolah negeri. Hal ini menyebabkan banyak guru yang belum tahu dan memahami penyusunan/pembuatan RPP secara baik/lengkap. Beberapa guru mengadopsi RPP orang lain. Hal ini, peneliti ketahui pada saat mengadakan supervisi akademik (supervisi kunjungan kelas) ke sekolah binaan. Permasalahan tersebut berpengaruh besar terhadap pelaksanaan proses pembelajaran.

Dengan keadaan demikian, peneliti sebagai pembina sekolah berusaha untuk memberi pendampingan pada guru dalam menyusun RPP Kurikulum secara lengkap sesuai dengan tuntutan Permendikbud 103 tahun 2014 dan standar penilaian Permendikbud 104 tahun 2014 yang merupakan bagian dari standar nasional pendidikan. Hal itu juga sesuai dengan harapan peneliti sebagai calon kepala sekolah bersamaan dengan kegiatan $O n$ the Job Learning (OJL) sekolah berdasarkan tugas dari LPPKS seorang calon kepala sekolah harus melakukan rencana tindak kepemimpinan untuk membina guru.

Rencana Pelaksanaan Pembelajaran harus dibuat agar kegiatan pembelajaran berjalan sistematis dan mencapai tujuan pembelajaran. Tanpa Rencana Pelaksanaan Pembelajaran, biasanya pembelajaran menjadi tidak terarah. Oleh karena itu, guru harus mampu menyusun RPP dengan lengkap berdasarkan silabus yang disusunnya. Rencana Pelaksanaan Pembelajaran sangat penting bagi seorang guru karena merupakan acuan dalam melaksanakan proses pembelajaran.

Berdasarkan latar belakang di atas, maka masalah-masalah yang muncul dapat diidentifikasikan sebagai berikut. (1) Guru banyak yang belum paham dan termotivasi dalam menyusun Rencana 
Pelaksanaan Pembelajaran Kurikulum 2013 dengan lengkap. (2) Sebagian besar guru belum mendapatkan pelatihan pengembangan Kurikulum 2013. (3) Ada guru yang tidak bisa memperlihatkan RPP Kurikulum 2013 yang dibuatnya dengan berbagai alasan. (4) RPP Kurikulum 2013 yang dibuat guru komponennya belum lengkap/ tajam khususnya pada komponen langkah-langkah pembelajaran dan penilaian. Berdasarkan latar belakang, identifikasi, dan pembatasan masalah di atas, diajukan rumusan masalah adalah

apakah dengan bimbingan berkel anjutan akan dapat meningkatkan kompetensi guru dalam menyusun RPP? Peneliti mencoba untuk mengambil tindakan dengan memberi penjelasan dan pendampingan serta arahan

kepada guru tentang pentingnya seorang guru membuat RPP secara lengkap. Dengan pendampingan diharapkan guru termotivasi dalam menyusun RPP dengan lengkap dan dapat digunakan sebagai acuan atau panduan dalam mengajar, agar $\mathrm{KI}$ dan KD yang terdapat dalam standar isi dapat tersampaikan semua karena sudah ada dalam RPP yang dibuat oleh guru. Untuk lebih jelasnya dapat dilihat pada siklus pertama. Peneliti mencoba untuk melihat proses peningkatan kemampuan guru dalam menyusun RPP melalui instrument proses yang telah dirancang yaitu berupa lembar observasi/pengamatan komponen RPP Kurikulum 2013 berdasarkan Permendikbud No 103 tahun 2013 yang memuat sembilan komponen yaitu: 1) identitas mata pelajaran, 2) kompetensi inti, 3) kompetensi dasar, 4) indikator pencapaian kompetensi, 5) materi ajar, 6) alokasi waktu, 7) kegiatan pembelajaran, 8) sumber belajar dan 9) penilaian hasil belajar ( soal, skor dan kunci jawaban ), untuk melihat apakah guru sudah membuat RPP dengan lengkap. Hal itu nanti akan dibuktikan dengan melihat RPP yang dibuat oleh guru. Terjadi peningkatan atau tidak pada siklus kedua. Penelitian Tindakan Sekolah (PTS) ini, bertujuan untuk meningkatkan kompetensi guru dalam menyusun Rencana Pelaksanaan Pembelajaran melalui pendampingan di sekolah binaan (SMPN Satu Atap Satu Bajawa). Penelitian Tindakan Sekolah (PTS) ini diharapkan dapat memberikan manfaat agar meningkatkan kemampuan profesionalisme peneliti untuk melakukan penelitian tindakan sekolah sesuai dengan permasalahan yang dihadapi di sekolah binaan peneliti. Meningkatkan kemampuan peneliti dalam menyusun serta menulis laporan dan artikel ilmiah. Sebagai motivasi bagi peneliti dalam membuat karya tu lis ilmiah. Dengan adanya pengalaman menulis, dapat memberikan bimbingan kepada teman-teman guru yang akan menulis. Hasil penelitian ini digunakan sebagai evaluasi terhadap guru dalam menyusun RPP yang selanjutnya akan digunakan sebagai bahan kajian kepada guru di sekolah. Akan berdampak adanya peningkatan administrasi guru pada KBM yang lebih lengkap. Dapat meningkatkan kualitas pendidika $\mathrm{n}$ karena Kompetensi Inti dan Ko mpetensi Dasar sudah tersampaikan. Bagi Guru, dapat 
meningkatkan kompetensi dalam membuat RPP dengan lengkap serta menciptakan kesadaran guru tentang tanggung jawabnya terhadap pelaksanaan tugasnya. Sebagai panduan dan arahan dalam mengajar sehingga apa yang diinginkan dalam standar isi dapat tersampaikan. Bagi siswa, adanya kesiapan belajar, keseriusan

keingintahuan, dan semangaat

belajar tinggi terhadap pelajaran. Siswa lebih percaya diri dalam mengikuti proses pembelajaran sehingga tercapai target kompetensinya.

\section{KAJIAN PUSTAKA Pendidik (Guru}

Secara etimologi (asal usul kata), istilah "Guru" berasal dari bahasa India yang artinya " orang yang mengajarkan tent ang kelepasan dari sengsara" Shambuan, Republika, ( dalam Suparlan 2005:11). Kemudian Rabindranath Tagore (dalam Suparlan 2005:11) menggunakan istilah Shanti Niketan atau rumah damai untuk tempat para guru mengamalkan tugas mulianya membangun spiritualitas anakanak bangsa di India (spiritual intelligence).

Pengertian guru kemudian menjadi semakin luas, tidak hanya terbatas dalam kegiatan keilmuan yang bersifat kecerdasan spiritual (spiritual intelligence) dan kecerdasan intelektual (intellectual intelligence), tetapi juga menyangkut kecerdasan kinestetik jasmaniah (bodily kinesthetic), seperti guru tari, guru olah raga, guru senam dan guru musik. Dengan demikian, guru dapat diartikan sebagai orang yang tugasnya terkait dengan upaya mencerdaskan kehidupan bangsa dalam semua aspeknya, baik spiritual dan emosional, intelektual, fisikal, maupun aspek lainnya.

Poerwadarminta

(dalam

Suparlan 2005:13) menyatakan, "guru adalah orang yang kerjanya mengajar." Dengan definisi ini, guru disamakan dengan pengajar. Pengertian guru ini hanya menyebutkan satu sisi yaitu sebagai pengajar, tidak termasuk pengertian guru sebagai pendidik dan pelatih. Selanjutnya Zakiyah Daradjat

(dalam

Suparlan 2005:13) menyatakan," guru adalah pendidik profesional karena guru telah menerima dan memikul beban dari orang tua untuk ikut mendidik anak-anak."

UU Guru dan Dosen Republik Indonesia No.14 Tahun 2005 "Guru adalah pendidik profesional dengan tugas utama mendidik, mengajar, membimbing, mengarahkan, melatih, menilai, dan mengevaluasi peserta didik pada pendidikan anak usia dini jalur pendidikan formal, pendidikan dasar, dan pendidikan menengah". Selanjutnya UU No.20 Tahun 2003 pasal 39 ayat 2 tentang sistem pendidikan nasional menyatakan, "pendidik merupakan tenaga profesional yang bertugas merencanakan dan melaksanakan proses pembelajaran, menilai hasil pembelajaran, melakukan pendampingandan pelatihan, serta melakukan penelitian dan pengabdian kepada masyarakat, terutama bagi pendidik pada perguruan tinggi."

$$
\text { PP No.19 Tahun } 2005
$$

tentang Standar Nasional Pendidikan menyatakan, "pendidik (guru) harus memiliki kualifikasi akademik dan kompetensi sebagai agen pembelajaran, sehat jasmani dan rohani, serta memiliki 
kemampuan untuk mewujudkan tujuan pendidikan nasional."

Berdasarkan definisi di atas, dapat disimpulkan bahwa guru adalah tenaga pendidik yang profesional dengan tugas utama mendidik, mengajar, membimbing, mengarahkan, melatih, menilai dan mengevaluasi peserta didik, dan bertugas merencanakan dan melaksanakan proses pembelajaran.

\section{Standar Kompetensi Guru}

Depdiknas

kompetensi diartikan, "sebagai pengetahuan, keterampilan, dan nilai-nilai dasar yang direfleksikan dalam kebiasaan berpikir dan bertindak" . "Secara sederhana kompetensi diartikan seperangkat kemampuan yang meliputi pengetahuan, sikap, nilai dan keterampilan yang harus dikuasai dan dimiliki seseorang dalam rangka melaksanakan tugas pokok, fungsi dan tanggung jawab pekerjaan dan/atau jabatan yang disandangnya" (Nana Sudjana 2009:1).

Nurhadi

menyatakan, merupakan keterampilan, dan nengetahuan, , dan nilai-nilai dasar yang direfleksikan dalam kebiasaan berpikir dan bertindak". Selanjutnya menurut para ahli pendidikan McAshan (dalam Nurhadi 2004:16) menyatakan, "kompetensi diartikan Sebagai pengetahuan, keterampilan, dan kemampuan yang dikuasai seseorang sebagai pengetahuan, keterampilan, dan kemampuan yang dikuasai seseorang yang telah menjadi bagian dari dirinya, sehingga dapat melakukan perilaku-perilaku koqnitif, afektif, dan psikomotor dengan sebaikbaiknya." $\begin{array}{cr}\text { Kompetensi } & \begin{array}{c}\text { diartikan } \\ \text { pengetahuan, }\end{array} \\ \text { sebagai } & \end{array}$ keterampilan, dan nilai-nilai dasar yang direfleksikan dalam kebiasaan berfikir dan bertindak (Dalam Suparlan). Arti lain dari kompetensi adalah spesifikasi dari pengetahuan, keterampilan, dan sikap yang dimiliki seseorang serta penerapannya di dalam pekerjaan, sesuai dengan standar kinerja yang dibutuhkan oleh lapangan.

Berdasarkan pendapat di atas dapat disimpulkan kompetensi adalah sebagai suatu kecakapan untuk melakukan sesuatu pekerjaan berkat pengetahuan, keterampilan ataupun keahlian yang dimiliki untuk melaksanakan suatu pekerjaan.

Undang-Undang Guru dan Dosan No.14 Tahun 2005 Pasal 8 menyatakan, "guru wajib memiliki kualifikasi akademik, kompetensi, sertifikat pendidik, sehat jasmani dan rohani, serta memiliki kemampuan untuk mewujudkan tujuan pendidikan nasional." Dari rumusan di atas jelas disebutkan pemilikan kompetensi oleh setiap guru merupakan syarat yang mutlak harus dipenuhi oleh guru. Dengan demikian, kompetensi yang dimiliki oleh setiap guru akan menunjukkan kualitas guru yang sebenarnya.

Selanjutnya Pasal 10 menyebutkan empat kompetensi yang harus dimiliki oleh guru yakni (1) kompetensi pedagogik, kompetensi kepribadian, kompetensi sosial, dan

kompetensi profesional. Kompetensi tersebut, akan terwujud dalam bentuk penguasaan pengetahuan, keterampilan, maupun sikap profesional dalam menjalankan fungsi sebagai guru. 


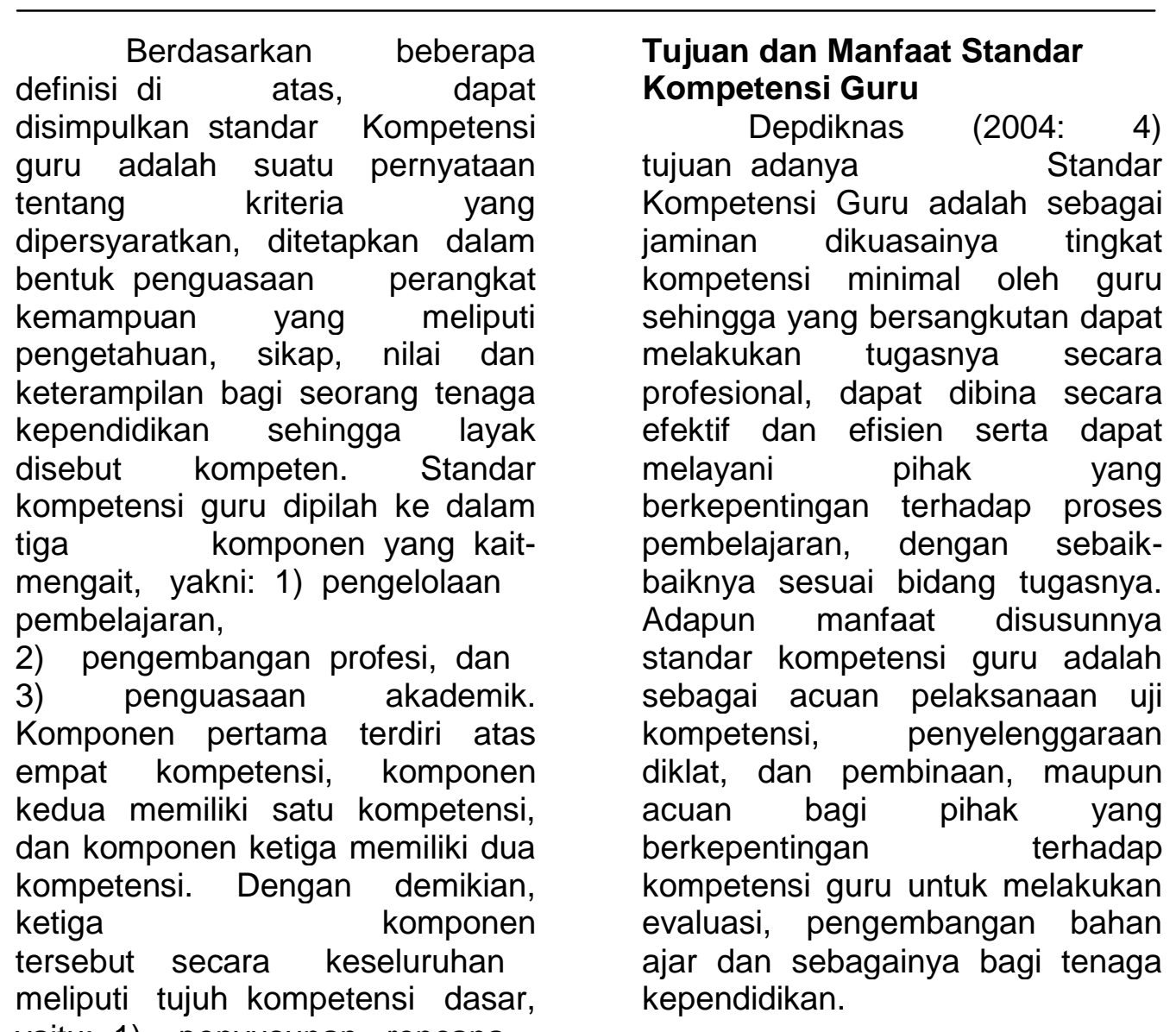

yaitu: 1) penyusunan rencana pembelajaran, 2)

pelaksanaan interaksi belajar mengajar, 3) penilaian prestasi belajar peserta didik, 4) pelaksanaan tindak lanjut hasil penilaian prestasi belajar peserta didik, 5)

pengembangan profesi, 6) pem ahaman wawasan kependidika $n$, dan 7) penguasaan bahan kajian akademik ( sesuai dengan mata pelajaran yang diajarkan). Abdurrahman Mas'ud (dalam Suparlan 2005:99) menyebutkan tiga kompetensi dasar

yang harus dimiliki guru, yakni:

(1) menguasai materi atau bahan ajar, (2) antusiasme, dan ( 3) penuh kasih sayang (loving) dalam mengajar dan mendidik.

\section{Rencana Pelaksanaan Pembelajaran (RPP)}

Perencanaan

proses

pembelajaran meliputi silabus dan RPP. Silabus merupakan sebagian sub-sistem pembelajaran yang terdiri dari atau yang satu sama yang lain saling berhubungan dalam rangka mencapai tujuan. Hal penting yang berkaitan dengan pembelajaran adalah penjabaran tujuan yang disusun berdasarkan indikator yang ditetapkan.

$$
\text { Philip Combs (dalam }
$$

Kurniawati, 2009:66), menyatakan bahwa perencanaan program pembelajaran merupakan suatu penetapan yang memuat komponen-komponen

pembelajaran secara sistematis. Analisis sistematis merupakan proses perkembangan pendidikan yang akan mencapai tujuan 
pendidikan agar lebih efektif dan efisien disusun secara logis, rasional, sesuai dengan kebutuhan siswa, sekolah, dan daerah (masyarakat). Perencanaan program pembelajaran adalah hasil pemikiran, berupa keputusan yang akan dilaksanakan

Selanjutnya Oemar Hakim (dalam Kurniawati 2009:74) menyatakan, "bahwa perencanaan program pembelajaran pada hakekatnya merupakan perencanaan program jangka pendek untuk memperkirakan suatu proyeksi tentang sesuatu yang akan dilakukan dalam kegiatan pembelajaran".

$$
\text { Permendiknas No. } 103
$$

tahun 2014 menyatakan, "Rencana Pelaksanaan Pembelajaran (RPP) adalah rencana yang menggambarkan prosedur dan pengorganisasian pembelajaran untuk mencapai satu kompetensi dasar dalam beberapa pertemuan yang mengacu

pada standar isi, standar kelulusan dan telah dijabarkan dalam silabus."

Berdasarkan pendapat di atas, dapat disimpulkan bahwa perencanaan pembelajaran adalah suatu upaya menyusun perencanaan pembelajaran yang akan dilaksanakan dalam kegiatan pembelajaran untuk mencapai tujuan yang telah ditetapkan dalam kurikulum sesuai dengan kebutuhan siswa, sekolah, dan daerah.

Dalam Kurikulum 2013, guru bersama warga sekolah berupaya menyusun kurikulum dan perencanaan program pembelajaran, meliputi: program tahunan, program semester, silabus, dan rencana peleksanaan pembelajaran. Rencana Pelaksanaan Pembelajaran dijabarkan dari silabus untuk mengarahkan kegiatan belajar peserta didik dalam upaya mencapai Kompetensi Dasar. RPP merupakan acuan guru dalam melaksanakan pembelajaran untuk setiap KD. Oleh karena itu, apa yang tertuang di dalam RPP memuat hal-hal yang langsung berkaitan dengan aktivitas pembelajaran dalam upaya pencapaian penguasaan suatu KD.

\section{Komponen Rencana \\ Pelaksanaan Pembelajaran}

Menurut Permendiknas

No. 103 Tahun 2014, komponen RPP terdiri dari (1). identitas mata pelajaran, (2) ko mpetensi inti, (3) kompetensi dasar, indikator pencapaian kompetensi,

(5) materi ajar, (6) alokasi waktu , (7) kegiatan pembelajaran dengan pendekatan saintific dan tematik integratif. (8) sumber belajar, (9) penilaian hasil belajar meliputi: soal, skor dan kunci jawaban.

$$
\text { Peraturan Pemerintah }
$$

Republik Indonesia No. 19 (2005 pasal 20) menyatakan bahwa, "RPP minimal memuat sekurang-kurangnya lima komponen yang meliputi: (1) tujuan pembelajaran, (2) materi ajar, (3) metode pengajaran, (4) sumber belajar, dan (5) penilaian hasil belajar."

\section{Prinsip-prinsip Penyusunan RPP}

Permendiknas No. 103 Tahun 2014 menyatakan dalam

menyusun rencana pelaksanaan pembelajaran harus memperhatikan prinsip-prinsip sebagai memperhatikan individu peserta didik, (2) men dorong partisipasi aktif 
peserta didik, (3) mengembangkan budaya membaca dan menulis, (4) memberikan umpan balik dan tindak lanjut, (5) keterkaitan dan keterpaduan, (6) menerapkan teknologi informasi dan komunikasi RPP .

\section{Langkah- langkah Menyusun RPP}

Langkah-

langkah menyusun RPP adalah

(1) mengisi kolom identitas,

(2) Menentukan alokasi waktu yang dibutuhkan untuk pertemuan yang telah ditetapkan, (3) Menentukan SK, KD, dan indikator yang akan digunakan yang terdapat pada silabus yang telah disusun, (4) Merumuskan indikator pencapaian berdasarkan $\mathrm{KI}, \quad \mathrm{KD}$, mengidentifikasi materi ajar berdasarkan materi pokok/pembelajaran yang terdapat dalam silabus, materi ajar merupakan uraian dari materi pokok/pembelajaran,

(6) merumuskan langkah-langkah yang terdiri dari kegiatan awal, inti dan akhir. (7) menentukan alat/bahan/sumber belajar yang digunakan, (8) menyusun kriteria penilaian, lembar pengamatan, contoh soal, teknik penskoran dan kunci jawaban

\section{Hal-hal yang Perlu Diperhatikan dalam Menyusun RPP}

Dalam penyusunan RPP perlu memperhatikan hal sebagai berikut: (1) RPP disusun untuk setiap KD yang dapat dilaksanakan dalam satu kali pertemuan atau lebih, (2) tujuan pembelajaran menggambarkan proses dan hasil belajar yang harus di capai oleh peserta didik sesuai dengan kompetenrsi dasar, (3) tujuan pembelajaran dapat mencakupi sejumlah indikator, atau satu tujuan pembelajaran untuk beberapa indikator, yang penting tujuan pembelajaran harus mengacu pada pencapaian indikator, (4) Kegiatan pembelajaran (langkah-langkah pembelajaran) dibuat setiap pertemuan, bila dalam satu RPP terdapat 3 kali pertemuan, maka dalam RPP tersebut terdapat 3 langkah pembelajaran, (5). Bila terdapat lebih dari satu pertemuan untuk indikator yang sama, tidak perlu dibuatkan langkah kegiatan yang lengkap untuk setiap pertemuannya.

\section{Pendampingan}

RM

Frank Parson. 1951 (dalam

Fatihah http://eko13.wordpress.co m) menyatakan, "pendampingansebagai bantuan yang diberikan kepada individu untuk dapat memilih, mempersiapkan diri dan memangku suatu jabatan dan mendapat kemajuan dalam jabatan yang dipilihnya." Chiskon 1959 (dalam RM Fatihah http://eko13.wordpress.com ) menyatakan, "pendampingan mem bantu individu untuk lebih mengenal berbagai informasi tentang dirinya sendiri". Berikutnya Bernard dan Fullmer 1969 (dalam RM Fatihah http://eko13.wordpress.com ) menyatakan, "bahwa

pendampingan dilakukan untuk meningkatkan perwujudan diri individu." Dapat dipahami bahwa pendampingan membantu individu untuk mengaktualisasikan diri dengan lingkungannya. Menurut Tim Redaksi Kamus Besar Bahasa Indonesia, "pendampingan adalah petunjuk penjelasan cara mengerjakan sesuatu, tuntutan." Dari beberapa 
pengertian pendampingan di atas, dapat

disimpulkan bahwa pendampingan adalah pemberian bantuan kepada individu secara berkelanjutan dar sistematis yang dilakukan oleh seorang ahli yang telah mendapat latihan khusus untuk itu,dimaksudkan agar individu dapat memahami dirinya, lingkungannya, serta dapat mengarahkan diri dan menyesuaikan diri dengan lingkungan untuk dapat mengembangkan potensi dirinya secara optimal untuk kesejahteraan dirinya dan kesejahteraan masyarakat. Menurut Redaksi Kamus Besar Bahasa

Indonesia, Pendampingan berlang sung terus menerus, berkesinambungan."

Berdasarkan

pengertian pendampingan dapat

disimpulkan

bahwa

pendampingan adalah pemberia $\mathrm{n}$ bantuan yang diberikan seorang ahli kepada seseorang atau individu secara berkelanjutan berlangsung secara terus menerus untuk dapat mengembangkan potensi dirinya secara optimal dan mendapat kemajuan dalam bekerja

\section{METODE PENELITIAN}

Setting dalam penelitian i ni meliputi: tempat

penelitian, waktu penelitian jadwal penelitian, dan siklus PTS adalah Penelitian Tindakan Sekolah dilaksanakan di sekolah sendiri berstatus negeri yaitu SMPN Satu Atap I Bajawa. Pemilihan sekolah tersebut ber tujuan untuk meningkatkan kom petensi guru dalam menyusun $r$ encana perlaksanaan pembelajar an (RPP) dengan lengkap. PTS ini dilaksanakan pada sem ester dua tahun 2019 selama

kurang lebih satu setengah bulan mulai April sampai dengan September 2019.

\section{Siklus Penelitian}

\section{Penelitian}

Sekolah dilaksanakan melalui dua siklus untuk

melihat peningkatan kompetensi guru dalam menyusun Rencana Pelaksanaan Pembelajaran (RPP). Sebelum PTS dilaksanakan, dibuat berbagai

input instrument yang digunakan untuk mendapatkan data dan informasi. Yang menjadi subjek dalam PTS ini adalah guru SMPN Satu Atap I Bajawa. Sumber data dalam PTS ini adalah rencana pelaksanaan pembelajaran yang sudah dibuat guru.

Teknik pengumpulan data

dalam penelitian ini adalah wawancara, observa si, dan angket. Wawancara dipergunakan untuk mendapatkan data atau informasi tentang pemahaman guru terhadap RPP Kurikulum 2013. Observasi dipergunakan untuk mengumpulkan data dan mengetahui kompetensi guru dalam menyusun Rencana Pelaksanaan Pembelajaran dengan lengkap. Diskusi dilakukan antara peneliti dengan guru. Alat pengumpulan data dalam PTS ini adalah Wawancara menggunakan panduan wawancara untuk mengetahui kemampuan awal yang dimiliki guru tentang Rencana Pelaksanaan

Pembelajaran Kurikulum 2013. Observasi menggunakan lembar observasi untuk mengetahui komponen RPP Kurikulum 2013 yang telah dibuat dan yang belum dibuat oleh guru. 
Diskusi dilakukan dengan
maksud untuk sharing pendapat
antara peneliti dengan guru.
Prosedur dalam penelitian ini
berbentuk Penelitian Tindakan
Sekolah (School Action
Research), yaitu sebuah penelitian
yang merupakan kerjasama antara
peneliti dan guru, dalam
meningkatkan kemampuan guru
agar menjadi lebih baik dalam
menyusun rencana pelaksanaan
pembelajaran.
Metode yang digunakan dalam penelitian ini adalah metode deskriptif, dengan menggunakan teknik persentase untuk melihat peningkatan yang terjadi dari siklus ke siklus. "Metode deskriptif dapat diartikan sebagai prosedur pemecahan masalah yang diselidiki dengan menggambarkan/melukiskan keadaan subjek/objek penelitian (seseorang, lembaga, masyarakat, dan lain-lain) pada saat sekarang berdasarkan fakta-fakta yang tampak atau sebagaimana adanya (Nawawi, 1985:63). Dengan metode ini peneliti menjelaskan data yan kumpulkan melalui $k$ langsung wawancara, observasi $/ \mathrm{f}$ $\mathrm{n}$, dan diskusi yang persentase atau angka-a Penelitian ini

untuk mendeskripsikan kesulitan yang diale guru dalam RPP. Selanjutnya memberikan alternatif a guna meningkatkan $k \epsilon$ guru dalam membuat pelaksanaan pembelajarc Hal-hal penting y diperhatikan dalam Tindakan menurut Sudarsono, F.X, (1999:2) yakni: (1) Rencana : Tindakan apa yang akan dilakukan untuk meningkatkan kompetensi guru dalam menyusun RPP secara lengkap. Solusinya yaitu dengan melakukan wawancara dengan guru dengan menyiapkan lembar wawancara, Diskusi dalam suasana yang menyenangkan dan memberikan pendampingan dalam menyusun RPP Kurikulum 2013 secara lengkap. (2) Pelaksanaan: Apa yang dilakukan oleh peneliti sebagai upaya meningkatkan kompetensi guru dalam menyusun RPP Kurikulum 2013 yang lengkap yaitu dengan memberikan pendampingan pada guru sekolah sendiri.

Observasi: Peneliti melakukan pengamatan terhadap RPP Kurikulum 2013 yang telah dibuat untuk memotret seberapa jauh kemampuan guru dalam menyusun RPP Kurikulum

2013 dengan lengkap, hasil atau dampak dari tindakan yang telah dilaksanakan oleh guru dalam mencapai sasaran.

Selain itu juga peneliti mencatat hal-hal yang terjadi dalam pertemuan dan wawancara. Rekaman dari pertemuan dan wawancara akan digunakan untuk analisis dan komentar kemudian.

Refleksi: Peneliti mengkaji, melihat, dan mempertimbangkan hasil atau dampak dari tindakan yang telah dilakukan. Berdasarkan hasil dari refleksi ini, peneliti bersama guru melaksanakan revisi atau perbaikan terhadap RPP Kurikulum 2013 yang telah disusun agar sesuai dengan rencana awal yang mungkin saja masih bisa sesuai dengan yang peneliti inginkan.

Prosedur penelitian adalah suatu rangkaian tahap-tahap 
penelitian dari awal sampai akhir. Penelitian ini merupakan proses pengkajian sistem berdaur sebagaimana kerangka berpikir yang dikembangkan oleh Kemmis dan Mc Taggarat. Prosedur ini mencakup tahap-tahap: perencanaan, (2) pelaksanaan, (3) pengamatan, dan refleksi. Keempat kegiatan tersebut saling terkait dan secara urut membentuk sebuah siklus. Penelitian Tindakan Sekolah merupakan penelitian yang bersiklus, artinya penelitian dilakukan secara berulang dan berkelanjutan sampai tujuan penelitian dapat tercapai". Berikut ini merupakan rancangan penelitian menurut Kemmis dan Mc Taggarat.

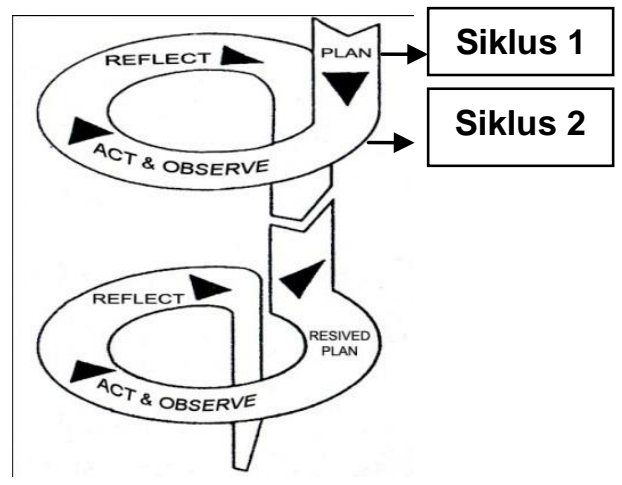

Rencana pelaksanaan dilakukan dalam dua siklus yaitu: Siklus Pertama (Siklus I ) Peneliti merencanakan tindakan pada siklus (membuat format/instrumen wawancara, penilaian RPP Kurikulum 2013, rekapitulasi hasil penyusunan RPP Kurikulum 2013). Peneliti memberi kesempatan kepada guru untuk mengemukakan kesulitan atau hambatan dalam menyusun Rencana Pelaksanaan Pembelajaran Kurikulum 2013. Peneliti menjelaskan kepada guru tentang pentingnya
RPP Kurikulum 2013 dibuat secara lengkap. Peneliti memberikan pendampingan dalam pengembangan RPP Kurikulum 2013. Peneliti melakukan observasi/pengamatan terhadap RPP Kurikulum 2013yang telah dibuat guru. Peneliti melakukan revisi atau perbaikan penyusunan rencana pelaksanaan pembelajaran yang lengkap. Peneliti dan guru melakukan refleksi. Siklus Kedua (Siklus II)

Peneiti merencanakan tindakan pada siklus II yang mendasarkan pada revisi/perbaikan pada siklus I, seperti menugasi guru menyusun RPP Kurikulum 2013 yang kedua, mengumpulkan, dan melakukan pendampingan penyusunan RPP Kurikulum 2013. Peneliti melaksanakan tindakan sesuai dengan rencana pada siklus II. Peneliti melakukan observasi terhadap RPP Kurikulum 2013 yang telah dibuat guru. Peneliti melakukan perbaikan atau revisi penyusunan RPP Kurikulum 2013. Peneliti dan guru melakukan refleksi. Peneliti mengharapkan secara rinci indikator pencapaian hasil paling rendah $78 \%$ guru membuat kesembilan komponen Rencana Pelaksanaan Pembelajaran sebagai berikut. (1) Komponen identitas mata pelajaran diharapkan ketercapaiannya $100 \%$. (2) Komponen kompetensi inti diharapkan ketercapaiannya 85\%. (3) Komponen kompetensi dasar diharapkan ketercapaiannya $85 \%$. (4) Komponen indikator pencapaian kompetensi diharapkan ketercapaiannya $75 \%$. (5) Komponen materi pembelajaran diharapkan kecercapaian $75 \%$. (6) Komponen alokasi waktu diharapkan ketercapaiannya $75 \%$. (7) Komponen langkah-langkah 
kegiatan pembelajaran diharapkan ketercapaiannya $\quad 70 \%$.

Komponen sumber belajar diharapkan ketercapaiannya $70 \%$. (9) Komponen penilaian diharapkan ketercapaia nnya $75 \%$.

\section{HASIL DAN PEMBAHASAN PENELITIAN}

Dari hasil wawancara terhadap delapan orang guru, peneliti memperoleh informasi bahwa semua guru (delapan orang) belum tahu kerangka penyusunan RPP Kurikulum 2013 , hanya sekolah yang memiliki dokumen standar proses (satu buah), hanya dua orang guru yang pernah mengikuti pelatihan pengembangan RPP Kurikulum 2013 , umumnya guru mengadopsi dan mengadaptasi RPP Kurikulum 2013 , kebanyakan guru tidak tahu dan tidak paham menyusun RPP Kurikulum 2013 secara lengkap, mereka setuju bahwa guru harus menggunakan RPP Kurikulum 2013dalam melaksanakan proses pembelajaran yang dapat dijadikan acuan/pedoman dalam proses pembelajaran. Selain itu, kebanyakan guru belum tahu dengan komponen-komponen RPP Kurikulum 2013 secara lengkap.

Berdasarkan hasil observasi peneliti terhadap delapan RPP Kurikulum 2013yang dibuat guru (khusus pada siklus I), diperoleh informasi/data bahwa masih ada guru yang tidak melengkapi RPP-nya dengan komponen dan sub-subkomponen RPP tertentu, misalnya komponen indikator dan penilaian hasil belajar (pedoman penskoran dan kunci jawaban). Rumusan kegiatan siswa pada komponen langkah-langkah kegiatan pembelajaran masih kurang tajam, interaktif, inspiratif, menantang, dan sistematis.

Dilihat dari segi kompetensi guru, terjadi peningkatan dalam menyusun Rencana Pelaksanaan Pembelajaran dari siklus ke siklus . Hal itu dapat dilihat pada lampiran Rekapitulasi Hasil Penyusunan RPP Kurikulum 2013 dari Siklus ke Siklus.

\section{Siklus I (Pertama)}

Siklus pertama terdiri dari empat tahap yakni: (1) perencanaan, (2) pelaksanaan, (3) observasi, dan (4) refleksi seperti berikut ini.

$\begin{array}{ll}1 . \quad P e r e n c a n a a n & \text { (Planning) } \\ \text { Membuat } & \text { lembar }\end{array}$
wawancara, Membuat format/instrumen penilaian RPP Kurikulum 2013, Membuat format rekapitulasi hasil penyusunan RPP Kurikulum 2013 persiklus, dan Membuat format rekapitulasi hasil penyusunan RPP Kurikulum 2013 dari siklus ke siklus.

2. Pelaksanaan (Acting)

Pada saat awal siklus pertama indikator pencapaian hasil dari setiap komponen RPP belum sesuai/tercapai seperti rencana/keinginan peneliti. Hal itu dibuktikan dengan masih adanya komponen RPP yang belum dibuat oleh guru. Sembilan komponen

RPP Kurikulum 2013 yakni: 1) identitas, 2) kompetensi inti, 3) kompetensi dasar, 4) indikator pencapaian kompetensi, 5) materi ajar, 6) alokasi waktu, 7) langkahlangkah

pembelajaran, 8 sumber

kegiatan

belajar, 9) penilaiaan hasil belajar ( soal, pedoman penskoran, dan kunci jawaban). Hasil observasi pada siklus kesatu dapat dideskripsikan berikut ini: 


Observasi dilaksanakan
Selasa, 13 April 2019, terhadap
delapan orang guru. Semuanya
menyusun RPP Kurikulum 2013,
tapi masih ada guru yang belum
melengkapi RPP-nya baik dengan
komponen maupun sub-sub
komponen RPP tertentu. Satu
orang tidak melengkapi RPP-nya
dengan komponen indikator
pencapaian kompetensi. Untuk
komponen penilaian hasil belajar,
dapat dikemukakan sebagai
berikut. Satu orang tidak
melengkapinya dengan teknik dan
bentuk instrumen. Satu orang tidak
melengkapinya dengan teknik,
bentuk instumen, soal, pedoman
penskoran, dan kunci jawaban.
Dua orang tidak melengkapinya
dengan teknik, pedoman
penskoran, dan kunci jawaban.
Satu orang tidak melengkapinya
dengan soal, pedoman penskoran,
dan kunci jawaban. Satu orang
tidak melengkapinya dengan
pedoman penskoran dan kunci
jawaban. Selanjutnya mereka
dibimbing dan disarankan untuk
melengkapinya.

\section{Siklus II (Kedua)}

Siklus kedua juga terdiri dari empat tahap yakni: (1) perencanaan, (2) pelaksanaan, (3) observasi, dan (4) refleksi. Hasil observasi pada siklus kedua dapat dideskripsikan berikut ini: Observasi dilaksanakan Selasa, 20 April 2019, terhadap delapan orang guru. Semuanya menyusun RPP Kurikulum 2013, tapi masih ada guru yang keliru dalam menentukan kegiatan siswa dalam langkah-langkah kegiatan pembelajaran dan metode pembelajaran, serta tidak memilah/ menguraikan materi pembelajaran dalam sub-sub materi. Untuk komponen penilaian hasil belajar, dapat dikemukakan sebagai berikut. Satu orang keliru dalam menentukan teknik dan bentuk instrumennya. Satu orang keliru dalam menentukan bentuk instrumen berdasarkan teknik penilaian yang dipilih. Dua orang kurang jelas dalam menentukan pedoman penskoran. Satu orang tidak menuliskan rumus perolehan nilai siswa. Selanjutnya mereka dibimbing dan disarankan untuk melengkapinya. Pada kondisi awal, peneliti melakukan observasi dan evaluasi untuk memberi skor dari keadaan awal terhadap kemampuan guru dalam menyusun RPP. Setelah melakukan pengamatan, diketahui kemampuan guru menunjukkan hasil sebagai berikut: (1) Satu Orang guru memperoleh nilai 86,36; (2) Satu Orang guru memperoleh nilai 77,27 ; (3) Satu Orang guru memperoleh nilai 75,00; (4) Satu Orang guru memperoleh nilai 72,72 , (5) Dua Orang guru memperolah nilai 59,09 , (6) Satu Orang guru memperoleh nilai 56,81 , dan (7) Satu Orang guru memperoleh nilai 54,54 .

Berdasarkan nilai hasil pengamatan pada masing-masing guru, maka peneliti akan membuat nilai rata-rata sesuai dengan rumus yang telah ditentukan sebelumnya. Kemudian dari nilai rata-rata akan ditemukan tingkat keberhasilan sesuai dengan indikator keberhasilan yang ditetapkan. Dari data di atas diperoleh nilai rata-rata 67,61

\section{Siklus 1}

Siklus 1 dilakukan berdasarkan hasil pengamatan dari kondisi awal. Pada siklus 1, didapatkan hasil pengamatan kemampuan guru dalam menyusun RPP sebagai berikut: (1) Satu Orang 
guru memperoleh nilai 100, (2) Satu Orang guru memperoleh nilai 84,09 , (3) Dua Orang guru memperoleh nilai 81,81 , (4) Satu Orang guru memperoleh nilai 75,00 , (5) Satu Orang guru memperoleh nilai 72,72 , (6) Satu Orang guru memperolah nilai 70,00 , (7) Satu Orang guru memperoleh nilai 65,90 .

Berdasarkan nilai hasil pengamatan pada masing-masing guru, maka peneliti akan membuat nilai rata - rata sesuai dengan rumus yang telah ditentukan sebelumnya. Kemudian dari nilai rata-rata akan ditemukan tingkat keberhasilan sesuai dengan indikator keberhasilan yang ditetapkan. Dari data diatas diperoleh nilai rata - rata 78,91.

\section{Siklus 2}

Berdasarkan hasil dari siklus 1, nilai rata-rata yang didapat dari hasil pengamatan belum mencapai indikator keberhasilan yang telah ditetapkan, yaitu 80,00. Oleh karena itu, diperlukan perbaikan pada siklus 2. Pada siklus 2, didapatkan hasil pengamatan kemampuan guru dalam menyusun RPP sebagai berikut: (1) Dua Orang guru memperoleh nilai 100 , (2) Dua Orang guru memperoleh nilai 95,45, (3) Satu Orang guru memperoleh nilai 93,18, (4) Dua Orang guru memperoleh nilai 84,09 , (5) Satu Orang guru memperolah nilai 79,54.

Berdasarkan nilai hasil pengamatan pada masing-masing guru, maka peneliti akan membuat nilai rata-rata sesuai dengan rumus yang telah ditentukan sebelumnya. Kemudian dari nilai rata-rata akan ditemukan tingkat keberhasilan sesuai dengan indikator keberhasilan yang ditetapkan. Dari data diatas diperoleh nilai rata-rata 91,47 .

\section{Pembahasan}

Penelitian

Tindakan

Sekolah dilaksanakan di SMPN

Satu Atap Satu Bajawa yang merupakan sekolah binaan peneliti berstatus swasta, terdiri atas delapan guru, dan dilaksanakan dalam dua siklus. Kedelapan guru tersebut menunjukkan sikap yang baik dan termotivasi dalam menyusun RPP Kurikulum 2013 dengan lengkap. Hal ini, peneliti ketahui dari hasil pengamatan pada saat melakukan wawancara

dan pendampingan penyusunan RPP Kurikulum 2013. Selanjutnya dilihat dari kompetensi guru dalam menyusun RPP Kurikulum 2013, terjadi peningkatan dari siklus ke siklus.

\section{Komponen Identitas}

Pada siklus pertama semua guru (delapan orang) mencantumkan identitas dalam RPP (melengkapi RPP-nya dengan identitas). Jika dipersentasekan, $84 \%$. Lima orang guru mendapat skor 3 (baik) dan tiga orang mendapat skor 4 (sangat baik). Pada siklus kedua, kedelapan guru tersebut mencantumkan identitas dalam RPP. Semuanya mendapat skor 4 (sangat baik). Jika dipersentasekan, $100 \%$, terjadi peningkatan $16 \%$ dari siklus I.

\section{Komponen Kompetensi Inti}

Pada siklus pertama semua guru (delapan orang) mencantumkan kompetensi inti dalam RPP-nya (melengkapi RPP-nya dengan standar kompetensi). Jika dipersentasekan yaitu $81 \%$. Masing-masing satu orang guru mendapat skor 1, 2, dan 3 (kurang baik, cukup baik, dan baik). Lima orang guru mendapat skor 4 
(sangat baik). Pada siklus kedua kedelapan guru tersebut mencantumkan standar kompetensi dalam RPP. Dua orang mendapat skor 3 (baik) dan enam orang mendapat skor 4 (sangat baik). Jika dipersentasekan, 94\%, terjadi peningkatan $13 \%$ dari siklus I.

\section{Komponen Kompetensi Dasar}

Pada siklus pertama semua guru (delapan orang) mencantumkan kompetensi dasar dalam RPP-nya (melengkapi RPP dengan kompetensi dasar). Jika dipersentasekan, $81 \%$. Satu orang guru masing-masing mendapat skor 1, 2, dan 3 (kurang baik, cukup baik, dan baik). Lima orang guru mendapat skor 4 (sangat baik). Pada siklus kedua kedelapan guru tersebut mencantumkan kompetensi dasar dalam RPP-nya. Dua orang mendapat skor 3 (baik) dan enam orang mendapat skor 4 (sangat baik). Jika dipersentasekan, 94\%, terjadi peningkatan $13 \%$ dari siklus I.

\section{Komponen Indikator Pencapaian Kompetensi}

Pada siklus pertama tujuh orang guru mencantumkan indikator pencapaian kompetensi dalam RPP-nya (melengkapi RPP-nya dengan indikator pencapaian kompetensi). Sedangkan satu orang tidak mencantumkan/melengkapinya.

Jika dipersentasekan, 56\%. Dua orang guru masing-masing mendapat skor 1 dan 2 (kurang baik dan cukup baik). Empat orang guru mendapat skor 3 (baik). Pada siklus kedua kedelapan guru tersebut mencantumkan indikator pencapaian kompetensi dalam RPP-nya. Tujuh orang mendapat skor 3 (baik) dan satu orang mendapat skor 4 (sangat baik). Jika dipersentasekan, 78\%, terjadi peningkatan $22 \%$ dari siklus I.

\section{Komponen Materi Ajar}

Pada siklus pertama semua guru (delapan orang) mencantumkan materi ajar dalam RPP-nya (melengkapi RPP-nya dengan materi ajar). Jika dipersentasekan, $66 \%$. Satu orang guru masingmasing mendapat skor 1 dan 4 (kurang baik dan sangat baik), dua orang mendapat skor 2 (cukup baik), dan empat orang mendapat skor 3 (baik). Pada siklus kedua kedelapan guru tersebut mencantumkan materi ajar dalam RPP-nya. Enam orang mendapat skor 3 (baik) dan dua orang mendapat skor 4 (sangat baik). Jika dipersentasekan, $81 \%$, terjadi peningkatan $15 \%$ dari siklus I.

\section{Komponen Alokasi Waktu}

Pada siklus pertama semua guru (delapan orang) mencantumkan alokasi waktu dalam RPP-nya (melengkapi RPP-nya dengan alokasi waktu). Semuanya mendapat skor 3 (baik). Jika dipersentasekan, $75 \%$. Pada siklus kedua kedelapan guru tersebut mencantumkan alokasi waktu dalam RPP-nya. Tiga orang mendapat skor 3 (baik) dan lima orang mendapat skor 4 (sangat baik). Jika dipersentasekan, 91\%, terjadi peningkatan $16 \%$ dari siklus I.

\section{Komponen Langkah-Langkah Kegiatan Pembelajaran}

Pada siklus pertama semua guru (delapan orang) mencantumkan langkah-langkah kegiatan pembelajaran dalam RPP-nya (melengkapi RPP-nya dengan 


\begin{abstract}
langkah-langkah kegiatan pembelajaran). Jika dipersentasekan, 53\%. Tujuh orang guru mendapat skor 2 (cukup baik), sedangkan satu orang mendapat skor 3 (baik). Pada siklus kedua kedelapan guru tersebut mencantumkan langkahlangkah kegiatan pembelajaran dalam RPP-nya. Satu orang mendapat skor 2 (cukup baik) dan tujuh orang mendapat skor 3 (baik). Jika dipersentasekan, 72\%, terjadi peningkatan $19 \%$ dari siklus I.
\end{abstract}

\section{Komponen Sumber Belajar}

Pada siklus pertama semua guru (delapan orang) mencantumkan sumber belajar dalam RPP-nya (melengkapi RPP-nya dengan sumber belajar). Jika dipersentasekan, 66\%. Tiga orang guru mendapat skor 2 (cukup baik), sedangkan lima orang mendapat skor 3 (baik). Pada siklus kedua kedelapan guru tersebut mencantumkan sumber belajar dalam RPP-nya. Dua orang mendapat skor 2 (cukup baik) dan enam orang mendapat skor 3 (baik). Jika dipersentasekan, 69\%, terjadi peningkatan 3\% dari siklus I.

\section{Komponen Penilaian Hasil Belajar}

Pada siklus pertama semua guru (delapan orang) mencantumkan penilaian hasil belajar dalam RPPnya meskipun sub-sub komponennya (teknik, bentuk instrumen, soal), pedoman penskoran, dan kunci jawabannya kurang lengkap. Jika dipersentasekan, 56\%. Dua orang guru masing-masing mendapat skor 1 dan 3 (kurang baik dan baik), tiga orang mendapat skor 2 (cukup baik), dan satu orang mendapat skor 4 (sangat baik). Pada siklus kedua kedelapan guru tersebut mencantumkan penilaian hasil belajar dalam RPP-nya meskipun ada guru yang masih keliru dalam menentukan teknik dan bentuk penilaiannya. Tujuh orang mendapat skor 3 (baik) dan satu orang mendapat skor 4 (sangat baik). Jika dipersentasekan, $78 \%$, terjadi peningkatan $22 \%$ dari siklus I.

Berdasarkan pembahasan di atas terjadi peningkatan kompetensi guru dalam menyusun RPP. Pada siklus I nilai rata-rata komponen RPP Kurikulum 2013 yakni 78,91 $\%$, pada siklus II nilai rata-rata komponen RPP Kurikulum 2013 yakni $\quad 91,47 \quad \%$, terjadi peningkatan $12,56 \%$.

Untuk mengetahui lebih jelas peningkatan setiap komponen RPP Kurikulum 2013, dapat dilihat pada lampiran Rekapitulasi Hasil Penyusunan RPP Kurikulum 2013 dari Siklus ke Siklus di SMPN Satu Atap I Bajawa (Lampiran 4). Setelah melalui beberapa tahapan tindakan dan hasil data yang diperoleh tiap tahapan dapat dijelaskan sebagai berikut: (1) Nilai rata-rata kemampuan guru dalam menyusun RPP pada tahap awal adalah 67,61 dengan predikat cukup baik, (2) Nilai rata-rata kemampuan guru dalam menyusun RPP pada siklus 1 adalah 78,91 dengan predikat baik, namun nilai yang diharapkan adalah 80,00, (3) Nilai rata-rata kemampuan guru dalam menyusun RPP pada siklus 2 adalah 91,47 dengan predikat sangat baik.

Jika dibuat dalam bentuk grafik , akan tampak seperti gambar di bawah ini: 


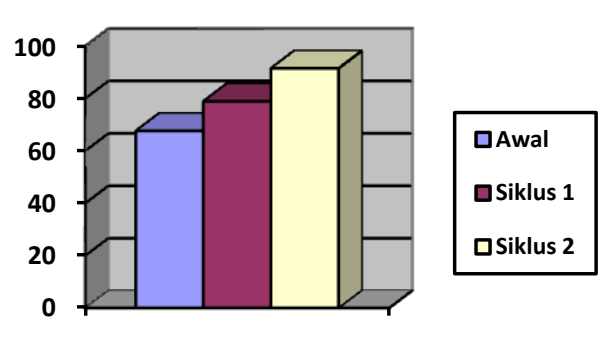

Gambar 1. Grafik Hasil Penelitian

Pada grafik diatas, dapat dijelaskan bahwa dengan diterapkannya bimbingan berkelanjutan guru pada SMPN SATAP I BAJAWA, maka guru mahir dan mampu menyusun RPP, hal ini terlihat dari hasil kondisi awal hingga siklus 2, terjadi peningkatan sehingga mencapai nilai indikator keberhasilan yang ditetapkan.

\section{SIMPULAN DAN SARAN}

\section{Simpulan}

Berdasarkan hasil dari pembahasan di atas, maka dapat disimpulkan bahwa Dalam bimbingan berkelanjutan dapat meningkatkan motivasi guru dalam menyusun RPP dengan lengkap. Guru menunjukkan keseriusan dalam memahami dan menyusun RPP apalagi setelah mendapatkan bimbingan penyusunan RPP. Informasi ini peneliti dapatkan dari hasil pengamatan pada saat wawancara dan bimbingan penyusunan RPP. Bimbingan berkelanjutan dapat meningkatkan kompetensi guru dalam menyusun RPP. Hal ini, dapat dibuktikan dari hasil observasi memperlihatkan

\section{DAFTAR PUSTAKA}

Daradjat,Zakiyah. 980. Kepribadian Guru. Jakarta: Bulan Bintang. terjadi peningkatan kompetensi guru dalam menyusun RPP dari siklus pertama ke siklus kedua. Pada siklus pertama nilai rata-rata komponen RPP 78,91 \% pada pada siklus kedua nilai rata-rata komponen RPP 91,47\%, terjadi peningkatan $12,56 \%$ dari siklus pertama.

\section{Saran}

Bimbingan berkelanjutan kepada guru dapat digunakan sebagai salah satu alternatif untuk meningkatkan kemampuan guru dalam menyusun RPP. Supervisi terhadap guru, terutama supervisi administrasi dapat dilaksanakan secara berkelanjutan dan optimal, agar memperoleh hasil sesuai dengan yang diharapkan. Supervisi terhadap guru hendaknya dilaksanakan oleh kepala sekolah secara optimal. Motivasi yang sudah tertanam khususnya dalam penyusunan RPP Kurikulum 2013 hendaknya terus dipertahankan dan ditingkatkan/ dikembangkan. RPP Kurikulum 2013 yang disusun/dibuat hendaknya mengandung komponen-komponen RPP secara lengkap dan baik karena RPP Kurikulum 2013 merupakan acuan/pedoman dalam melaksanakan pembelajaran. Dokumen RPP Kurikulum

2013 hendaknya dibuat minimal dua rangkap, satu untuk arsip sekolah dan satunya lagi untuk pegangan guru dalam melaksanakan proses pembelajaran.

Depdiknas. 2003. UU RI No. 20

Tahun 2003 tentang Sistem Pendidikan asional.Jakarta: Depdiknas. 


\section{Standar Kompetensi Guru Sekolah Dasar. Jakarta: Depdiknas. \\ 2005. UU RI No. 14 Tahun 2005 tentang Guru dan Dosen. Jakarta: Depdiknas.}

\section{Standar Nasional Pendidikan. Jakarta: Depdiknas.} 2007. Permendiknas RI No. 41 Tahun 2007a tentang Standar Proses. Jakarta: Depdiknas.

2008. Perangkat

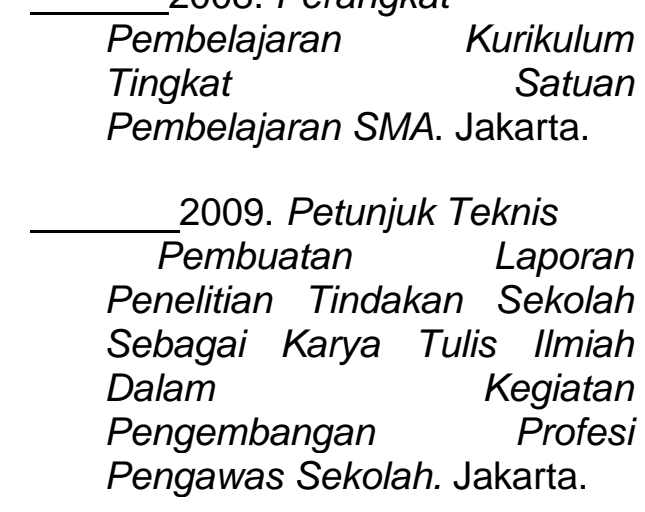

Kemendiknas. 2019. Penelitian

Tindakan Sekolah. Jakarta.
2019. Supervisi

kademik. Jakarta. Nawawi, Hadari. 1985. Metode Penelitian Bidang Sosial. Yogyakarta: Gadjah Mada University Press.

Nurhadi. 2004. Kurikulum 2004. Jakarta: PT Gramedia Widiasarana Indonesia.

Pidarta, Made . 1992. Pemikiran Tentang Supervisi Pendidikan. Jakarta: Bumi Aksara.

Sudjana, Nana. 2009. Standar Kompetensi Pengawas Dimensi dan Indikator. Jakarta : Binamitra Publishing.

Suharjono. 2003. Menyusun Usulan Penelitian. Jakarta: Makalah Disajikan pada Kegiatan Pelatihan Tehnis Tenaga Fungsional pengawas.

Suparlan. 2005. Menjadi Guru Efektif. Yogyakarta: Hikayat Publishing. 2006. Guru Sebagai Profesi. Yogyakarta: Hikayat Publishing. 